\title{
Barbara Harriss-White
}

People of the same trade seldom meet together, even for merriment and diversion but the conversation ends in a conspiracy against the public, or in some contrivance to raise prices'

(Adam Smith, 1776/1976, Wealth of Nations, $p$ 144)

This is an attempt at a comparative analysis of the political organization of foodgrains markets under different conditions of agrarian structure and state regulatory intervention. In particular, the analysis focuses on the role of collective political activity in rice markets in three case areas: (i) an arid but longcommercialized and well-urbanized region of capitalist agriculture relying on water control via well irrigation. The grain market was studied at a time of considerable state regulation comprising state trading, storage, processing and controls over the conditions of open market trading (Coimbatore District in South India in 1979-80 (Harriss 1981, 1984, 1991a)); (ii) a pauperized, inegalitarian and largely rainfed rizicultural system (that supplying Dhaka, the capital of Bangladesh in 1988) with state intervention largely contingent on expectations of market supply (Harriss 1989) and (iii) a heterogeneous agrarian region, historically the epicentre of sharecropping, which has undergone tenurial reform plus reforms to rural credit and labour markets, where local government has been decentralized and party-politicized but where state regulation of the market is weakly developed (Bardhama District of West Bengal in 1990 (Harriss 1991b)).

Indian merchants have been characterized as political marginalized. Fox's pioneering study in North India, for instance, concluded that traders were cut off from the society in which they functioned and that their political involvement was a) minimal and b) defensive (Fox 1968). In foodgrains marketing systems which the early post-Independence research concluded on the whole to be operating competitively and efficiently, the possibility of collusive activity (either economic or political) was ruled out

1 This body of research was conducted on the basis of ideas about the relation between structure and behaviour borrowed unsystematically and therefore not looked for (Cummings 1967; Jasdanwall 1966; Lele 1971). ${ }^{1}$ With this empirical background, we started the comparative project with three somewhat contradictory hypotheses about mercantile politics: first, that the state would shape the space for the politics of market organization - the greater and more effective the state intervention (as in Coimbatore) the less the scope for collective action by merchants; second, that where the ecological environment is uncertain and hazard-prone (as it is in Bangladesh and West Bengal) state regulatory control over merchants trading in the means of subsistence would be most systematized; third, that mercantile politics would be limited in its objectives to the defence of merchants' independence of other significant social groups, and would be most defensive where agriculture and industry were technologically advanced (as in Coimbatore).

\section{THE ECONOMIC INSTITUTIONS OF SOUTH ASIAN FOODGRAINS MARKETS: A CARICATURE}

Marketing systems have been relatively under-researched despite, or perhaps because of, their institutional complexity. While the commodity exchange relations of producers have been theorized for conditions of inegalitarian peasant agriculture (Bharadwaj 1974) and of sharecropping (Bhaduri 1983), the institutional attributes of commodity markets in these models are never specified. In Bharadwaj's formulation 'the market' is implicitly competitive and in Bhaduri's it has to consist of a strategic alliance of landlord, moneylenders and traders (whose internal conflicts of interest are then explored).

Yet, far from being a simple layer between producers and consumers, real grain markets present a bewildering diversity of institutions, organizational forms and technical functions. Although these market institutions maintain a varying degree of autonomy with respect to forms and institutions of agriculture production (such that real markets can

by agricultural economists from industrial organization theory. 
certainly not be read off deterministically from production relations) some of the variation in market institutions and behaviour is regional and seems a response not only to the technical requirements of the crop and the agrarian structure, but also the specificities and serendipities of distributions of capital and information and to the actual substance of state intervention. There is no consensus about the key features which could shape any characterization of actually existing grain markets. However, attributes common to all regions compared here include the following:

i Trade is gendered, with women tending to appear in two ways. Women from pauperized households are confined to petty and often seasonal operation, to subsistence orientation and 'simple reproduction', particular positions and activities within the system (especially processing and retailing), local territorial linkages, weekly marketplace sites and unlicensed and/or illegal transactions. Alternatively women are used for the caste-based reproduction and expansion of larger firms by means of their dowries on marriage and through their unwaged provision of that part of the wage to labour in trading firms which takes the form of prepared food. The wholesale trade (and its politics) is thus almost completely male territory.

ii Commodities are far from homogeneous. In South India, 120 varieties of rice have their prices tracked, with constrained substitution possibilities and complex, seasonally-changing, spatial flows. The market for rice is therefore a bundle of economic markets.

iii A range of organizational forms coexist. These range from self-employment on a petty and intermittent basis through family firms (without or with wage labour) to joint stock companies via cooperatives and many types and conditions of parastatals. The mix of activities in these firms are extremely diverse. These tendencies towards uniqueness in activity combinations prevent comparative analysis at the level of the firms and make it impossible to distinguish the returns from trade from returns generally. Likewise, the competitive conditions within the post-harvest production and trading system vary at each of the multiple states of transfer of property rights.

2 Accumulation by petty firms is also constrained because of higher per unit trading and transactions costs and because of the relative size iv Large numbers of agents conceal a distribution of mercantile assets combining massive polarization and concentration (Gini assets and output coefficients of 0.6-0.75 are normal - considerably greater than those for land and production) so that 'oligopolies', for want of a better word, coexist with crowded, petty trade. Major entry barriers to the latter subsector are gender and caste rather than capital or information, though there are high and rising barriers of the last sorts protecting the local oligopolies. Important fractions of petty trade are not independent but tied. The mercantile oligopolies strive to set the terms and conditions of accumulation of the petty sector by relations of finance. ${ }^{2}$ Small firms are also dependent on large ones for information, and physical facilities such as storage, processing and transport for which rental markets commonly evolve.

$\mathbf{v}$ Forms of contract range from spot contracts (very rare, though these are supposedly the price data collected by the state) through advance and/or futures agreements (common), through repeated or relational forms (common and structured in networks based upon caste or locality) to internalized transfers within vertically integrated firms. Contracts are usually verbal except where state scrutiny is involved, where they are often written in pencil. Contracts are socially loaded, in the sense that they may effect the transfer of rights of control not only over tangible commodities, but also over intangibles (loyalty, 'quality', reliability). Rules of adherence may be formal and legal or customary.

vi Markets are spatially and socially differentiated. Common patterns involve periodic markets with concentrations of petty trade, wholesale markets with the full range of institutional diversity and wholesale sites arranged dendritically for regional (occasionally international) export.

vii Average rates of return to marketing hide a great range which are affected by the extent to which wage labour is used. Rates of return also vary with activity combinations. Wherever they have been compared, however, returns to 'trade' exceed those from agricultural production, agro processing and from segments of the informal money markets. 
viii Close links between grain marketing and grain production in the investment portfolios of mercantile firms. This takes two forms. One is in which production is controlled directly through the ownership of land. Though subject to great variation, the landholding of traders is greater than in the population as a whole and also likelier to be rented out. The other linkage leads to an indirect control over production through preharvest credit tied to postharvest sales. This latter can involve several tiers of more or less tied trading intermediaries who lend onward at higher (implicit) interest until the post-harvest supplies of financially dependent producers are captured.

ix Diversified investment portfolios are being created by the oligopolistic subsector of merchants with tendencies towards urban property, finance, agro processing and commerce itself and much less commonly in land or industry 'proper'. Resources are switched in contingent fashion between the components of such portfolios rendering the calculation of returns to marketing per se ever more stylized for merchant and analyst alike.

\section{PUBLIC POLICY, PARTY POLITICS AND THE FOODGRAINS TRADES}

Stateintervention in grain markets is not an exogenous force acting on these markets in a consistent way. Historically, foodgrains marketing policies have been characterized by a profound ambivalence and a clash of political and economic logic. On the one hand, there are bodies of local regulatory law involving many departments of government and specifying in fine detail the legal conduct of open markets (and exacting fees which are often the only light taxation leviable on the staple foodgrains). These laws rest on the assumption that such markets are satisfactorily efficient and competitive and that the state may perform a minimalist role.

On the other hand, there are marketing cooperatives, storage corporations and state and central government grain trading corporations which manage domestic procurement (and food aid and imports in Bangladesh), store food reserves and subsidize dis- tribution to shifting targets - on the explicit assumption that markets are so unacceptably uncompetitive that they require partial replacement.

In practice, state intervention not only carries out these contradictory functions (with emphases and at scales which vary over time), it also provides opportunities for the pervasive extraction of rent at lower levels of the various food bureaucracies. The mechanisms comprise a plethora of regulatory actions which maximize the private discretionary power of state employees at the same time as creating or exacerbating market price distortions which increase profits to certain private traders. The majority of government departments have mandates directly covering some aspect of agricultural marketing. State and market are thus enmeshed contradictorily at the formal level and less contradictorily in practice in a nexus of interests in the redistribution of the resources appropriated in marketing through a combination of bureaucratic rent and excess profit. ${ }^{3}$

All our case studies have confirmed Fox's observation that traders' party political involvement is minimal and fragmented. Both because of the economic linkages between production and trade within a market system and because of the extreme heterogeneity of market institutions, merchants do not form a homogeneous social or party-political group, despite their importance to the economy. Political parties in South Asia are on the whole not classbased. Nor has a given political party been found to have a coherent policy on private trade at the local level at which markets actually exist.

Mercantile politics has at its centre the defence of the oligopoly. This defence is rarely expressed in party political alignments, yet there are three responses to party politics practised by traders. One is to eschew party political contamination altogether. This is rarer than suggested by characterizations of merchants as social outsiders influenced by Vysya ethics of piety and avoidance of obligation. ${ }^{4}$ The second is also practised by a minority and consists of the reverse: active political participation in party politics, especially in its funding. But this political support runs across the gamut of parties including the Communist Parties ('after all Engels owned a
3 The detailsof such accommodations and the political and economic challenges to them have been set out elsewhere (Harriss 1984).

4 Vysyas are the third caste group in the Hindu order with trade as their vocation. They are lower in purity than Kshatriyas (warriors) and Brahmins (priests) and higher than Sudras (cultivators), service castes and outcastes. But all caste groups except the latter are found as traders in markets; and outcastes may be found as labourers in physical contact with paddy in stores, mills and trucks, though much more rarely with milled rice. 
factory') and is nowhere confined to one. The third response is that of the Vicar of Bray. It consists of financial support for the ruling party of the day. This is political opportunism rather than neutrality.

Mercantile political expression takes its most active form not in party politics but in specialist collective institutions. It is via trade associations that the interests of the oligopoly are served. The rest of this article examines how they work in three different circumstances.

\section{Southern Tamil Nadu}

Grain merchants participate in institutions which are non-party political in purpose in a much more active way than they do in party politics, and with an intensity which bears a general relation to size of enterprise. Two of these types of institution are closely associated with the state - cooperatives and the local panchayats. They are often captured by merchants of the sort who are also party politically active. Political conditions then exist for the subordination of state institutions designed to replace private trade to the interests of private merchants.

Another two types of collective, 'civil-society' institution are focuses of big merchants' politics. One set consists of social service institutions (Lions, Rotary Clubs, Jaycees and the imitative Rotracters, $Y^{\prime}$ 's, Men's clubs, the Inner and Outer Wheels and even Masonic Lodges) all dedicated to philanthropic and humanitarian concerns. In fact, their practical activity consists of acts of particularistic redistributivist charity which serve to reinforce the prestige in which large merchants are held by their peers. Social ties between big grain merchants, local industrialists, lawyers and bureaucrats evolve out of such social institutions. This social cement is another factor conducive to the subordination of the public interest to those of private merchants. The other set in this category involves the collective administration of temples. Not only does such office-holding illustrate piety, it also illustrates control over temple assets such as land and urban property. Since this property may constitute the physical fabric of the marketplace, such merchants can exert control over market entry, over rents (and thus indirectly over profits of less powerful traders).

While a minority of grain merchants participate in the institutions discussed so far, commodity associations are joined by all traders with licences. These associations are based on locality, with memberships ranging from 25 to 150 . They were provoked into existence in the late 1960s and 1970s for one or more of three purposes.

First and foremost they represent a deliberate institutional response by grain merchants to the unionization of the casual labour necessary to markets. Merchants have had to develop institutional mechanisms for the negotiation of wage rates and terms and conditions of work. The relative importance of this aspect of associational politics depends on locality for not all market places have organized labour. The casual female labour force (fluid, working intermittently, dispersed in terms of origin) is not organized anywhere - outside the scope of political party activists, a condition very convenient to merchants. Negotiations are subtle because merchants, organized by commodity, confront workers stratified by job type (cutting across commodity lines) and organized into a series of unions by several competing political parties.

The second raison d'etre of commodity associations is the defence of their markets from 'threat' (regulation) by the state. Such 'threats' include i) the nature of the regulatory agenda e.g. exaction of Regulated Market fees, the imposition of movement restrictions, levies or quota sales to the state distribution system at prices less than those 'ruling', ii) the way in which such regulations are implemented e.g. harassment by the vigilance forces at roadside excise checkposts, absence of consultation by state institutions over milling rates, outturn standards of rice from paddy, and wages to be paid by millers on contract to the state and iii) penalties imposed for evasion of the regulatory laws e.g. for unlicensed operation, for storage in excess of limits on quantity or periodicity or for defiance of the welfare provisions of the Labour Laws.

Here politics operates through lobbying and there is the possibility, through hierarchical federations, of lobbying up to the highest political levels, though in the region studied this was rare. Lobbying is most usually local and aimed at the political apparatus, the fragmented executive administration of the state and parastate, the police and judiciary. Grain merchants rarely mobilize when policy is formulated, working instead on the process of policy implementation. Their lobbying may be rhetorical and persuasive or involve financial transfers; it may be oppositional or it may actually be collaborative depending on very precise circumstances. In this process, technically illegal privileges and concessions may be won, some of which may benefit all 
members but some of which can often be gained individually, with the association manipulated as a legitimating label and with conflict between the collective private interest and the private interest of individual traders (which generates its own politics). While the political activity of small associations may be intermittent and dominant for long periods of time, that of the apex institutions at the state level is continuous. The instability of many aspects of market regulation would seem very consistent with this type of politics.

The third type of challenge to mercantile power here is from agricultural capital. This has often been expressed in well organized, agitational forms, by capitalist farmers who conscript the mass of the peasantry, appealing to the state not only for amortization on overdue electricity bills, for increased inputs subsidies and infrastructural concessions but also for reforms to 'the market'. Here the conflict of interests of landed merchants who are also members of such farmers' movements has the potential to be debilitating to the latter. Reforms to commodity markets have been less successfully wrested from the state by organized farmers than have subsidies on agricultural inputs supplied by state administered institutions (such as surface irrigation, credit and electricity) because of the organized opposition of merchants' associations whose leading members may be landed and therefore may be active in agricultural protest.

Thus in Coimbatore District we found the marketing system to be a sizable, defended, political interface between agriculture and industry within the food economy. In addition, merchants' collective institutions defend their interests against challenges by labour and encroachments from the state. In participating and controlling a range of other institutions of civil society, big merchants can exert regulatory pressure over the market behaviour of smaller firms. Grain merchants are organized so as to influence in their own interests any level of the state polity and even the actions of rival lobbies. They have done so with demonstrable success.

\section{The Dhaka Region of Bangladesh}

Grain merchants within Bangladesh's capital city have been in the process of being organized for much longer than they have in rural South India. Yet, there are considerable similarities between these extremely contrasting conditions in their forms of mercantile politics: in their size and organization on the basis of locality; in the universality of their membership (in Dhaka the Hindu minority is completely represented just as the Muslim minority is represented in the predominantly Hindu region of Coimbatore); in the tendency for opportunistic political alignments: in the prominence (if not the domination) of grain merchants in institutions of local government, social and cultural institutions; in their predisposition to philanthropic display and in their lobbying of government to the highest levels of which they have easy and informal access. There is abundant evidence (Harriss 1989; Crow and Murshid 1991) pointing not to a conflict of interests between state and market but rather to a consensus of bureaucratic and commercial interests in the misimplementation of regulatory intervention, economic mechanisms of which operate both collectively and individually. The administration benefits from bureaucratic rent. Consider for an example, the Food Department's mill gate procurement policy, started in 1985 where 'influence' was used by organized merchants in the negotiation of paddy-rice conversion ratios ensuring very high private returns. Individual local officials are then paid by individual millers at several points: i) in order to obtain the milling agreement with the Food Department; ii) at the moment of issue of a Weight Quality Storage Certificate; and iii) to obtain repayment by the Food Department for milling for state distribution. But 'there is an institutionalized distribution of the returns from these charges' widely within the local offices and up to District Headquarters. There is a nationwide auction for the post of District Commissioner of Food in one of the food surplus areas of Bangladesh (Crow and Murshid 1991: 95). Traders and millers in turn derive profit from price distortions engendered by such forms of policy implementation. Here however we will focus on the dissimilarities between the associational politics of rural Coimbatore and urban Dhaka.

The self-styled Merchants' Trades Unions were not created reactively in response to the political organization of their labour forces. Instead collective action became necessary because of labour problems resulting from the different way in which labour is organized in grain marketing: particularly because of opportunistic transactions by itinerant traders, networks of whom have been customarily attached to single wholesalers.

Nor have the associations been provoked so much by state regulation, though this is undoubtedly a reason for their current strength. By contrast the administration found the existence of such associa- 
tions positively useful as a mechanism by which it can inform and exert pressure on private trade. This is especially necessary in a hazard-prone ecological environment. That there is yet no federation of associations to facilitate this task - no collective chain of command and considerable ignorance about the modus operandi of other associations - may be seen as a form of institutional retaliation on the part of merchants. This unfederated lobbying is directed less at economic aspects of market regulation than in Coimbatore and more at costs and risks caused by physically disrupted utilities.

The political muscle of coolies (the manual labour force of marketplaces) has grown only latterly. The struggle over surplus between organized merchants and organized labour (the formalization of which began earlier in India though is still far from complete) is only just starting in certain market places in the Dhaka region. Wage rates to labour are fixed by the merchants' associations but handed down by fiat to labourers. Negotiations about prices are more focused on lorry and boat rates. Operators of transport are well organized and transport is far more underdeveloped and uncertain in Bangladesh than it is in South India.

The organization of these associations is less participative than in Coimbatore with activity concentrated in the hand of inner committees of traders who are rarely elected for this job but who form networks of the economically powerful. At the same time grain associations in Dhaka are more structured than in Coimbatore and involve employed staff and specialist premises. The funding of mercantile associations by monthly subscription is more systematic and on a relatively much larger scale in the Dhaka region than in Coimbatore District.

More strikingly and related to the scale of funding of these associations, while law and order activities are rarely carried out by the Indian associations, they are routine and important functions of the grain merchants' associations in Dhaka. Arbitration of disputes is the main means by which associations impose order. Commonest disputes involve default on credit advances, non-customary undercutting, the use of false weights and measures and crime and loss in transport. Methods such as publicity, abuse and shaming are deployed. The associations can enforce compliance by threats to block all other transactions by the offender. They can also evict offenders. The Dhaka rice marketplaces are sites for a comparatively high incidence of robbery, violence and riot- ous behaviour. In the absence of adequate police support, grain associations have organized their own security forces.

Formidable local power is thus held by grain merchants but there are limits to their collective action. No association has succeeded in systematizing bank credit for trade so that loans are reported by the merchants concerned to be cornered by the very largest merchants. Private payments to officials of the food and income tax departments and the licensing authorities were reported to be individualized. Terms and conditions of contracts are intensely and competitively individualized.

So, despite the critical role played by grain in this economy and the hazardous conditions under which it is distributed, the regulatory capacity of the state in Bangladesh appears to be more limited than it is in those parts of India where the grain lobby has previously been examined. Even the minimum role of the state in guaranteeing contract and physical security, without which markets cannot function, rests on more fragile foundations in Bangladesh. Merchants in Dhaka have to channel their collective political energy into the basic activities of security, the resolution of disputes, the speeding of prosecution by the official forces of law and order and, by default, the organization of private forces of security. The notable lack of an association of associations increases the friction with which the state manipulates these collective institutions. At times of the flood or other crisis, the head of state has to bargain directly with each association. But the associations are manipulated in turn by powerful individual merchants so that a system of corruption and excess profiteering has been cemented.

\section{Rural West Bengal}

In Bardhaman District of West Bengal, the collective activity of merchants is dominated by the need for a different prerequisite to marketing than physical security. This is the state provision of regulation. Although a Regulated Agricultural Markets Actstipulating the terms and conditions for the first transaction between producer and trader has been enacted in West Bengal as in all other states of India, it has never been implemented. West Bengal's agricultural markets are nevertheless quite densely regulated by means of a mass of laws and enforcement mechanisms involving a number of different government departments (Revenue, Cooperation, Agriculture, Social Welfare and Local Government, etc.). However, as with the Regulated Markets Acts else- 
where in the subcontinent, these laws are also hardly ever implemented as laid down. They are transformed beyond recognition in implementation. They can be completely ignored. They can be creatively reinterpreted by verbal renegotiation to the mutual advantage of bureaucrats and traders (for example the cases of paddy and rice procurement from millers by state trading corporations, and the restriction of 'formal' sector credit to biggest merchants). They may be flouted by the powerful and imposed on the weak (for example, the capture of the potato crop by cold store owners; the use of rationing of licences to oppress unlicensed traders by bribery to officials and usurious moneylending to hapless unlicensed merchants). They may be used to regulate behaviour by threat backed by a very occasional penalization. Finally, the implementation of these laws may be the basis of the preemptive evolution of marketing systems (as in the casualization of labour to avoid the Factories Acts obligations). They are implemented so as to create a system of diffused appropriation of bureaucratic rent by individuals and sometimes by networks scattered through the majority of departments.

The institutional means whereby grain markets are regulated is actually diverse. The state plays a negligible role. Regulation is underdeveloped. Norms for marketing (such as weights and measures) are not completely standardized. Property rights are less secure than in South India. Regulation is either privately and individually organized where costly externalities can be internalized (as with security, hygiene and crime detection) or institutionalized collectively.

Very recently, there has mushroomed a meso level set of associational institutions in the political space between marketing firms and the state. As we have seen with the other case studies, they have been brought into existence to respond in a collective way to representations from collective labour institutions and to these regulations of the state. But they also perform crucial regulating functions within their commodity markets as well as other overlapping activity. In a rather disorganized way, structured both by locality and by position in the marketing system, these collective institutions organize:

i ownership of market sites as the collective property of the association;

ii exploiting scale economies (e.g. in transport, guarding, waste disposal); iii putting up entry barriers against non members;

iv colluding over prices;

$\mathbf{v}$ risk spreading and insurance (e.g. cases of interest free group credit and group insurance by subscription for accident, calamity, fraud or legal expenses);

vi physical security and a tolerable public health environment in marketplaces;

vii reduction in the transactions costs associated with trading (information not just in the form of pertinent facts about prices but about production, supply, important transactions, fraud and delinquency (the circulation of which is confined to the group); calibration of weights and measures, dispute resolution and enforcement);

viii reduction of uncertainty on related or derived markets (collective negotiation of advantageous set maximum rates - for labour, transport and processing);

ix expressions of social coherence, philanthropy and piety.

The performance of grain markets regulated in such a way judged by price integration analysis (Palaskas and Harriss 1991) is inefficient in the short term. Spatial price margins far exceed transport costs. Paddy and rice price differentials far exceed processing costs.

Not all of these groups are lawful. Nor are all of them durable. Associations which have failed have done so for reasons of adverse selection (as when the costs of including illegal mills have destroyed the financial base) or reasons of opportunistic behaviour and co-variate risk (which destroyed a traders' credit association). It is the weakest agents in this marketing system who are unable to organize (petty paddy-rice processors, female retailers, unlicensed husking millers): 'we are always in fear and cannot group'.

It can be concluded from this case study that where the state is unable to or unwilling to implement regulatory laws, civil society institutions step in to perform this function, but with little evidence to date of efficiency and a lot more evidence of institutional conflict and of the exercise of coercion against those deliberately excluded. 


\section{CONCLUSION}

In contradistinction to Fox's conclusion and to the impression to be gained from their party political participation, merchants - at least these grain merchants - have been found to be far from politically marginal. Pace Smith, they conspire to a great deal more than the raising of prices. Their apparently fragmented institutional allegiances disguise political linkages which enable the mercantile elite both individually and collectively to organize the terms of market participation of smaller traders.

The hypotheses about politics with which we embarked proved to be inadequate. From the three case studies it can be seen that under conditions of relatively effective state regulation, it is not the case that there is less scope for organizational politics. The associations in South India bore down on all policy tendrils seeking to curb their power. Here we also saw these collective institutions defending merchants' interests against labour and against agricultural producers. Secondly, where the ecological environment is uncertain and both it and the economy are hazard prone, state control over staple food merchants was expected to be most systematic. That this is not the case testifies to the relative power of private traders. It also means that merchants have to engage in DIY - in Bangladesh organizing their own security and in West Bengal organizing their own regulation. Lastly, we did indeed find mercantile politics to be defensive, both literally and institutionally in Bangladesh and most defensive in Coimbatore, but this was due not so much to the political organization of agricultural and industrial producers as to the political and economic irritations of organized labour and the existence of a more effective regulating state. We have seen however that the organized political activity of merchants operates with more complex tactics than defence alone.

Grain merchants in South Asia have organized themselves collectively in reaction to challenges tending to come from three sources: the unionization of labour; regulatory activity by the state; and the need for autoregulation in the absence of effective state regulation in the context of the development of long distance interregional trade. While the intentionality of such collective institutions cannot be in doubt, their malleability has also become evident. Once brought into existence, traders' organizations can develop a variety of new political roles according to circumstance.
Institutional economists such as Williamson would argue that such organizations are efficient ways of minimizing transactions costs in markets (1985). This unverifiable $e x$ post rationalization overlooks the price inefficiency of markets regulated like this, the deployment of collective institutions as political mechanisms not only for the collective private economic interest but also for the individual private interest and their coercive penalization of those excluded. In the reactive, defensive politics which builds up around these collective institutions, mercantile power also extends into other institutions of municipal and local government, religion, education, culture and social welfare.

Civil-society institutions in private markets play a distinctly ambivalent role. Markets cannot develop without them, yet they simultaneously restrict entry and institutionalize distribution in ways which may not be desired by the mass of society. Their operation causes the state to become more accountable but accountable to merchants. Any attempt by the state to intervene in markets has to deal with the political fact of these collective institutions. A developmental state might not wish to leave regulation entirely in the hands of these institutions for the very good reasons that their penalties on outsiders are often oppressive and extralegal, and that they function to protect their own interests in highly differentiated market structures. They are quite capable of preventing the organization of weaker intermediaries.

So, lastly, a social engineering question which is extremely important in the context of the 'deregulation' accompanying structural adjustment clamours for consideration. How to maximize the benefits from mercantile collective institutions while reducing the social costs of mercantile collective action. Two responses suggest themselves, though residualizing the issue of the means of improving both state and social accountability (which is what is involved in such responses) feels distinctly irresponsible.

First, state trading and storage institutions and cooperatives do not have a distinguished track record of regulating private markets by means of competition. From the evidence presented here we would not construct a case for the expansion of state intervention even though it is now easier to see how one might be argued. It is more fruitful to examine the scope for reform of the regulatory laws which at least on paper enshroud private markets. In the case 
of markets, the law needs to be implementable. The detail of such reform is well outside the scope of this discussion, but certain elements can be outlined: reforms to reduce the at present intense specificity of the trading conduct deemed to be lawful and instead to delineate transactions that are unlawful, thereby legitimating a broader transactional space; a systematized and centralized system of administration, taxation and enforcement to replace the multiple, diffuse and localized ones existing now; laws and rules which operate via positive incentives rather than negative strictures; improvements to specification at the boundaries, where one set of rules, such as that for private markets meets others, such as those for state trading or commercial taxation.
Second, encouragement might be given to other civil society institutions to regulate merchants. Associations of market labourers, even of agricultural producers, have not proved up to the mark as yet. Movements of public awareness, consumer groups and lobbies, women's' groups, conscientizing and empowering NGOs especially those mobilizing the numerically enormous 'middle class' may prove more successful - per se, or in concert with other social organizations. Until now however, consumer politics has been particularly notable for its absence, weakness or lack of coherence throughout most of the subcontinent, for reasons which may not be unconnected with grain merchants' organized power.

\section{REFERENCES}

Bharadwaj, K., 1984, Production Conditions in Indian Agriculture, London: Cambridge University Press

Bhadururi, A., 1983, The Economics of Backward Agriculture, New York: Academic Press

Crow, B. and Murshid, K.A.S., 1991, 'Foodgrain markets in Bangladesh: traders, producers and policy', Report to ODA, Milton Keynes: Open University

Cummings, R.W.Jnr., 1967, Pricing Efficiency in the Indian Wheat Market, New Delhi: Impex

Fox, R.G., 1968, From Zamindar to Ballot Box, Ithaca:Cornell University Press

Harriss, B., 1981, 'Agricultural mercantile politics and policy: acase study of Tamil Nadu', Economic and Political Weekly, Vol XVI No 10-12: 441-58

1984, State and Market, New Delhi: Concept

1989, 'Organized power of grain merchants in the Dhaka region of Bangladesh', Economic and Political Weekly, March 25: A39-44 1991a, 'Masters of the countryside: a regional political economy of agricultural markets in an advanced district of South India', Report to ODA, Oxford: International Development Centre

1991b, 'Markets, society and the state: problems of marketing of smallholder agriculture in West Bengal', Report to WIDER, Helsinki, Oxford: International Development Centre

Jasdanwall, Z.Y., 1967, Marketing Efficiency in Indian Agriculture, Bombay: Allied Publishers

Lele, U.J., 1971, Foodgrains Marketing in India: Private Performance and Public Policy, Ithaca: Cornell University Press

Palaskas, T.B., and Harriss, B., 1991, 'Testing market integration: new approaches with case material from the West Bengal food economy', Working Paper 126, Oxford: Institute of Economics and Statistics

Williamson, O.E., 1985, The Economic Institutions of Capitalism, New York: Free Press 